\title{
A Reappraisal of the Role of Insulin-like Growth Factor I in the Regulation of Human Hematopoiesis
}

\author{
Mariusz Z. Ratajczak, ${ }^{\star}$ Wojciech I. Kuczynski, * Kazufumi Onodera, * Jonni Moore, * Janina Ratajczak, * \\ David A. Kregenow, ${ }^{\star}$ Kim DeRiel, ${ }^{\S}$ and Alan M. Gewirtz ${ }^{\star \ddagger}$ \\ Departments of *Pathology and ${ }^{\ddagger}$ Internal Medicine, University of Pennsylvania School of Medicine, Philadelphia, Pennsylvania 19104; \\ and ${ }^{\S}$ Fels Cancer Research Institute, Temple University School of Medicine, Philadelphia, Pennsylvania 19140
}

\begin{abstract}
IGF-I has been reported to increase hematopoietic progenitor cell cloning efficiency. To investigate this phenomenon, we studied the IGF-I responsiveness of human marrow cells expressing IGF-I receptor (IGF-IR), a direct strategy not used previously. IGF-IR ${ }^{+}$and control $\mathrm{CD34}^{+}$marrow cells were isolated using immunoaffinity methods. Then, the cells were cloned in methylcellulose containing variable amounts of serum- and lineage-appropriate growth factors supplemented with recombinant human IGF-I. In contrast to $\mathrm{CD34}^{+}$cells, IGF-IR ${ }^{+}$cells never gave rise to CFU-Blast, CFU-Mix, CFU-GM, BFU-E, or CFU-E. To substantiate the suggestion that $\mathrm{CD}^{+} 4^{+}$and $\mathrm{IGF}-\mathrm{IR}^{+}$cells were distinct populations, we used reverse transcription PCR to detect IGF-I, EpO, and KIT receptor mRNAs in these cells. The mRNA phenotype of $\mathrm{CD}^{+} 4^{+}$cells was EpO $(+), \operatorname{KIT}(+)$, and IGF-IR $(-)$, while IGF-IR ${ }^{+}$cells were IGF-IR $(+)$, EpO (-), and KIT (-). These results suggested that IGFIR is either not expressed or expressed at low levels on normal hematopoietic progenitor cells. Functional significance of the latter possibility was tested by exposing $\mathrm{CD}^{+}$ cells to IGF-IR antisense oligodeoxynucleotides. Colony formation was unaffected by oligodeoxynucleotide disruption of IGF-IR, suggesting that, even if expressed at low level, the receptor's functional significance was doubtful. Nevertheless, when cultured in the presence of IGF-I, IGF-IR ${ }^{+}$ cells elaborated an activity with mild BFU-E stimulatory effects. Accordingly, if IGF-I plays a role in hematopoietic colony formation, it is probably indirect and results from stimulation of IGF-IR-positive ancillary cells to secrete growth factors. Studies carried out with human leukemia cells yielded similar results. (J. Clin. Invest. 1994. 94:320327.) Key words: hematopoiesis • insulin-like growth factors - insulin-like growth factor I receptor • antisense oligodeoxynucleotides $\cdot$ leukemia
\end{abstract}

Address correspondence and reprint requests to Mariusz Ratajczak and Alan M. Gewirtz, Room 230 - John Morgan Building, University of Pennsylvania School of Medicine, 36th Street and Hamilton Walk, Philadelphia, PA 19104.

A preliminary report of these studies was presented at the XXXIV Annual Meeting of the American Society of Hematology in Anaheim, CA on 7 December 1992.

Received for publication 13 December 1993 and in revised form 10 February 1994.

J. Clin. Invest.

(c) The American Society for Clinical Investigation, Inc.

0021-9738/94/07/0320/08 \$2.00

Volume 94, July 1994, 320-327

\section{Introduction}

IGF-I and IGF-II are known mitogens for a variety of cell types, including those of the hematopoietic cell system (1). IGF-I, which is synthesized in liver and bone marrow stromal cells in response to pituitary growth hormone (2), has been particularly well studied in this regard. In murine model systems, IGF-I infusions will stimulate hematopoiesis $(3-5)$ and pre-B and $\mathrm{T}$ lymphocyte development (6-8) and are capable of reversing the anemia caused by the administration of antiretroviral drugs (5). In studies with human leukemia cell lines, IGF-I has been shown capable of enhancing the growth of several types including K-562, Daudi, KG-1, and HL-60 $(9,10)$. In normal human cells, IGF-I will stimulate the formation of erythroid burst- and colony-forming units (BFU-E and CFU-E, respectively) ${ }^{1}$ under low (11) or serum-free conditions (12-15), and antibodies to IGF-I receptor (IGF-IR) have been reported to block these effects (11). IGF-I will also stimulate granulocyte colony formation (16) and the generation of free radicals by granulocytes and macrophages (17). More recently, IGF-I, along with $\beta$ fibroblast growth factor, was found to be necessary for proliferation of human fetal bone marrow $\mathrm{CD} 34^{+}, \mathrm{CD} 38^{-}$, and HLA$\mathrm{DR}^{-}$cells containing precursors of both the hematopoietic and stromal elements (18). Finally, antisense oligodeoxynucleotides to IGF-IR have been reported to inhibit HL-60 cell growth as well as the growth of peripheral blood mononuclear cells stimulated with IL-2 and phorbol 12-myristate 13-acetate (19).

Though there seems to be little doubt that IGF-I has trophic effects on hematopoietic cell development, the mechanism for this effect is uncertain. A number of studies have suggested that the effect is a direct one $(12,14)$ since the hormone will stimulate relatively pure populations of erythroid progenitor cells (12), even in the apparent absence of accessory cells (12). Further, autoradiography studies suggest that ${ }^{125}$ I-labeled IGFI will bind to CFU-E $(12,20)$. However, in the course of investigating the role of the erythropoietin (EpO) receptor in erythroid cell development, we found to our surprise that IGF$\mathrm{IR}^{+}$marrow mononuclear cells did not give rise to hematopoietic colonies in response to EpO, IGF-I, or a number of other hematopoietic cell growth factors. Accordingly, we decided to revisit this aspect of IGF-I biology to determine if its effects

1. Abbreviations used in this paper: AML, acute myelogenous leukemia; AS, antisense; $\mathrm{A}^{-} \mathrm{T}^{-} \mathrm{MNC}$, adherent and $\mathrm{T}$ lymphocyte-depleted mononuclear cells; BCS, bovine calf serum; BFU-E, burst-forming unit of erythrocytes; CFU-Blast, CFU of Blasts; CFU-E, CFU of erythrocytes; CFU-GM, CFU of granulocytes and macrophages; CFU-Meg, CFU of megakaryocytes; CFU-Mix, CFU of mixed lineages; EpO, erythropoietin; IGF-IR, IGF-I receptor; KL, kit ligand; ODN, oligodeoxynucleotides; $\mathrm{rH}$, recombinant human; RT-PCR, reverse transcription PCR. 


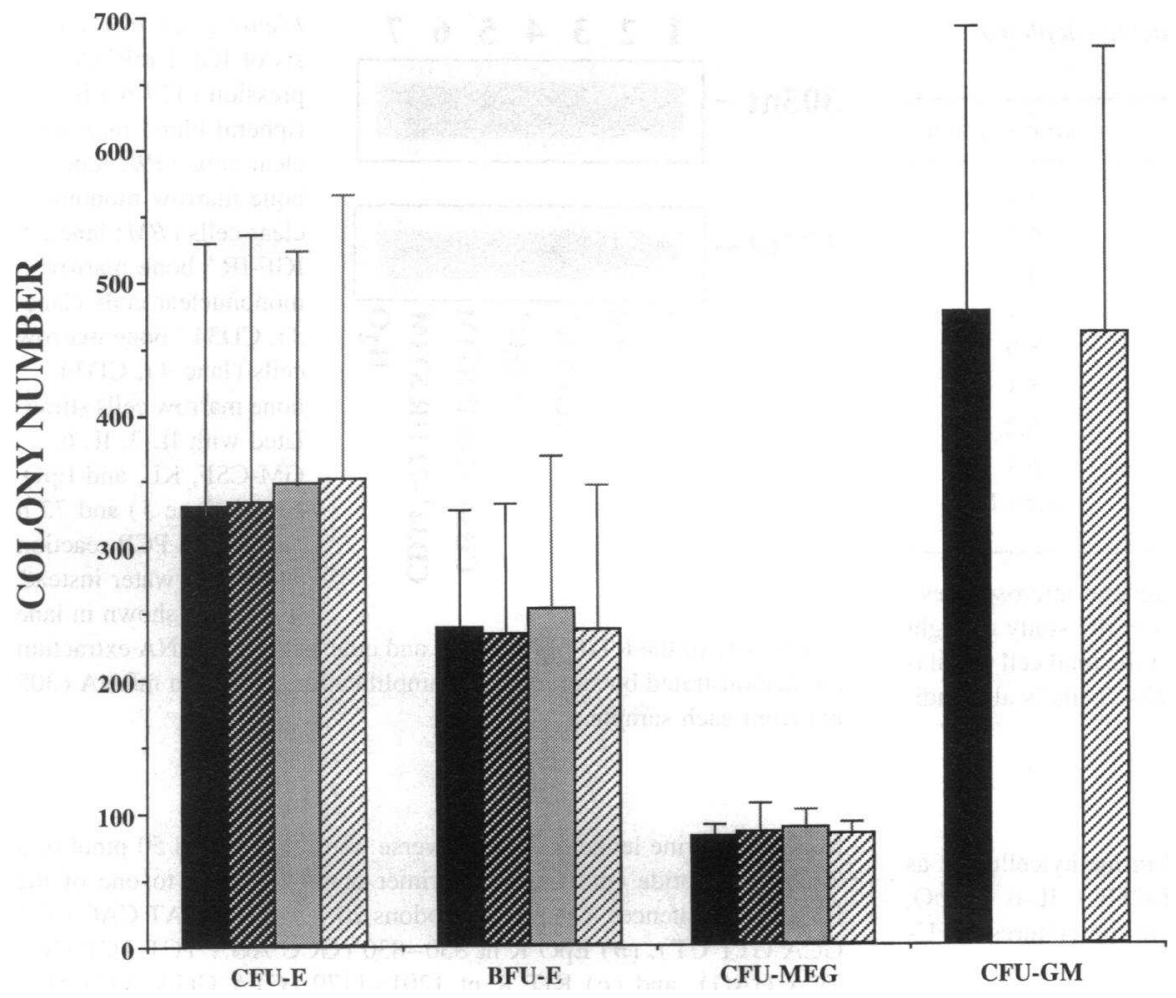

Figure 1. Effect of rH IGF-I on colony formation by human hematopoietic progenitor cells. CFU-Meg and CFU-E colonies were cloned from $\mathrm{A}^{-} \mathrm{T}^{-} \mathrm{MNC}$ (10 $/$ dish); BFU$\mathrm{E}$ and CFU-GM colonies were cloned from CD $34^{+} \mathrm{MNC}\left(10^{4} / \mathrm{dish}\right)$. Colony formation was stimulated with lineage-appropriate growth factors as described in Methods. IGF-I was added to cultures at concentrations of: $0 \mathrm{ng} / \mathrm{ml} \mathrm{( \square ),} 10 \mathrm{ng} / \mathrm{ml}(\Xi), 50$ $\mathrm{ng} / \mathrm{ml}(\boldsymbol{\square})$, and $100 \mathrm{ng} / \mathrm{ml}(\square)$. CFU-GM colonies were cloned only in the presence of IGF-I at the $100 \mathrm{ng} / \mathrm{ml}$ concentration. on hematopoietic cell development were directly mediated as implied in the literature or were indirect. We also attempted to determine when in the course of hematopoietic progenitor cell development IGF-IR was expressed or if it was expressed at all. To carry out these studies we used purified cell populations and growth factors and also performed receptor disruption studies with antisense oligodeoxynucleotides. We found that IGF$\mathrm{IR}^{+}$cells are indeed present in human bone marrow, but, in contrast to $\mathrm{CD} 34^{+}$cells, this population does not express c-kit or EpO receptors and does not give rise to hematopoietic colonies. These data suggest that the IGF-IR ${ }^{+}$and $\mathrm{CD} 4^{+}$populations of marrow cells are nonoverlapping. They further suggest that the effect of IGF-I is likely indirect and is perhaps mediated by $\mathrm{IGF}_{\mathrm{IR}}{ }^{+}$ancillary cell population whose role is to synthesize growth factors in response to binding of the ligand.

\section{Methods}

Cells. Light density marrow mononuclear cells were obtained from consenting normal donors and depleted of adherent cells and $\mathrm{T}$ lymphocytes $\left(\mathrm{A}^{-} \mathrm{T}^{-} \mathrm{MNC}\right.$ ) as described previously (21). CD34 ${ }^{+}$and IGF-IR ${ }^{+}$cells were isolated from the $\mathrm{A}^{-} \mathrm{T}^{-}$MNC population with immunomagnetic beads (Dynal AS, Oslo, Norway) or by fluorescence activated cell sorting. Cells bearing these respective phenotypes were identified with anti-CD34 (Becton Dickinson \& Co., Mountain View, CA) or antiIGF-IR (Oncogene Science Inc., Manhasset, NY) mAbs.

Briefly, $\mathrm{A}^{-} \mathrm{T}^{-} \mathrm{MNC}\left(2 \times 10^{7}\right)$ were incubated with the appropriate primary $\mathrm{mAb}$ (1:20 dilution in $1 \mathrm{ml}$ of Iscove's with $5 \%$ bovine calf serum $[B C S]$ ) for positive selection of the desired surface antigen. For immunomagnetic separations, cells were incubated in the primary $\mathrm{mAb}$ with gentle rocking for $1 \mathrm{~h}$ at $4^{\circ} \mathrm{C}$, washed $3 \times$ in Iscove's medium with $5 \% \mathrm{BCS}$, and then incubated (45 min, room temperature) with $150 \mu \mathrm{l}$ of magnetic beads coated with sheep anti-mouse IgG. Cells affixed to the magnetized beads were isolated with a magnet according to the manufacturer's directions (21). After washing in Iscove's medium plus $10 \%$ BCS, the cells were used for cloning experiments. For FACS ${ }^{\circledR}$ isolation, cells were suspended in PBS supplemented with 5\% BCS and labeled with anti-CD34 or anti-IGF-IR mAbs as described above, followed by washing ( $3 \times$ in PBS plus 5\% BCS) and incubation (45 $\min , 4^{\circ} \mathrm{C}$ ) with goat anti-mouse FITC (1:40) (Boehringer Mannheim $\mathrm{GmbH}$, Mannheim, Germany). Cells were then analyzed for fluorescence labeling. The brightest $5 \%$ of cells were defined as antigen positive and subsequently sorted for cell culture studies.

Human leukemia cell lines were obtained from American Type Culture Collection (Rockville, MD). Leukemia cells were cultured in RPMI with $2 \%$ heat-inactivated $\left(56^{\circ} \mathrm{C}\right.$ for $\left.0.5 \mathrm{~h}\right) \mathrm{FCS}$ or "serum-free" in HL1 tissue culture medium (Ventrex Labs., Portland, ME). Cells were seeded into 96 -well microtiter plates $\left(2 \times 10^{4} / \mathrm{ml}\right)$.

Cell cultures. Positively selected $A^{-} T^{-} \mathrm{MNC}\left(10^{5} / \mathrm{ml}\right), \mathrm{CD} 34^{+}$ $\left(10^{4} / \mathrm{ml}\right)$, or IGF-IR ${ }^{+}$cells $\left(2 \times 10^{4}\right)$ were suspended in $0.4 \mathrm{ml}$ of Iscove's medium plus $10 \%$ BCS and mixed with $1.8 \mathrm{ml}$ of HCC-17 medium (Terry Fox, Vancouver, Canada). The appropriate growth factors were added to the mixture, which was then transferred to $3.5-\mathrm{cm}$ plastic Petri dishes and incubated $\left(37^{\circ} \mathrm{C}, 95 \%\right.$ humidity, $\left.5 \% \mathrm{CO}_{2}\right)$ for the period of time appropriate to the colonies which were being grown. Growth factors for stimulating the various progenitors were as follows: CFU-E-EpO (5 U/ml); BFU-E-(EpO + IL-3 [20 U/ml]) or (EpO + kit ligand [KL] [100 ng/ml]); CFU-GM-IL-3 (20 U/ml) + GMCSF ( $5 \mathrm{ng} / \mathrm{ml})$; CFU-Mix-EpO (5 U/ml) + KL (100 ng/ml) + IL-3 $(20 \mathrm{U} / \mathrm{ml})+$ GM-CSF $(10 \mathrm{ng} / \mathrm{ml})+\mathrm{IL}-6(40 \mathrm{U} / \mathrm{ml})$. CFU-Blast were grown according to the method of Ogawa and co-workers (22). Recombinant human $(\mathrm{rH})$ growth factors were used in all experiments. rH IGF-I was purchased from Genzyme Corp. (Cambridge, MA). KL was the kind gift of Immunex Corp. (Seattle, WA); EpO, IL-3, and GM-CSF were the generous gifts of Genetics Institute (Cambridge, MA); IL-6 was the generous gift of the Robert Wood Johnson Pharmaceutical Research Institute (Raritan, NJ).

Colonies were counted with an inverted microscope on days 7 (CFUE), 11 (CFU-GM), 14 (BFU-E), and 15 (CFU-Mix). CFU-Meg colonies were identified and counted as described previously (21). Early 
Table I. Phenotype of Adherent and T Lymphocyte-depleted Normal Human Marrow Mononuclear Cells

\begin{tabular}{ccc}
\hline Donor & $\mathrm{A}^{-} \mathrm{T}^{-}$MNC \% CD34 & $\mathrm{A}^{-} \mathbf{T}^{-}$MNC \% IGF-IR $^{+}$ \\
\hline 1 & 1.4 & 3.7 \\
2 & 2.3 & 6.2 \\
3 & 3.2 & 4.9 \\
4 & 1.9 & 7.1 \\
5 & 4.1 & 5.9 \\
6 & 3.3 & 5.1 \\
7 & 2.1 & 5.2 \\
8 & 2.3 & 6.1 \\
Mean \pm SD & $2.6 \pm 1$ & $5.5 \pm 1$ \\
\hline
\end{tabular}

Phenotyping was carried out by labeling with magnetic microspheres as described in Methods. Results were derived from the study of eight normal donors and are expressed as a percentage of the total cell population. For comparison purposes, percentage of $\mathrm{CD}^{2} 4^{+}$cells is also indicated.

CFU-Blast-like colonies were cultured for $14 \mathrm{~d}$ in methylcellulose as described (22) at which time $\mathrm{KL}+\mathrm{IL}-3$ + GM-CSF + IL-6 + EpO, at concentrations used for CFU-Mix, was added to the cultures. CFUBlast colonies were counted on day 28.

Preparation of low serum medium. Low serum medium was prepared by mixing $2.3 \%$ methylcellulose ( $40 \mathrm{ml}$ of HCC 4100 ; Terry Fox ) with HL-1 serum-free medium ( $30 \mathrm{ml}$; Ventrex Labs.). This basic mix was supplemented with $5 \mathrm{ml}$ each of $10 \%$ Cohn fraction V BSA (Boehringer Mannheim GmbH) and BCS (Hyclone Laboratories, Logan, UT) and $1 \mathrm{ml}$ of L-glutamine. The serum content was $55 \%$.

Oligodeoxynucleotides (ODN). Unmodified 18-base ODN were synthesized on a DNA synthesizer (model 380B; Applied Biosystems, Inc., Foster City, CA) by means of $\beta$-cyanoethyl phosphoroamidite chemistry as reported previously $(21,23)$. ODN were purified by ethanol precipitation and multiple washes in $70 \%$ ethanol. They were subsequently lyophilized to dryness and redissolved in culture medium at a concentration of $1 \mu \mathrm{g} / \mu \mathrm{l}(0.167 \mathrm{mmol} / \mathrm{liter})$. ODN sequences used were based on the published human IGF-IR sequence (24). They were targeted to codons $21-26$ of the signal sequence of the subunit of IGF-IR preceding the proreceptor sequence (25) and were as follows: antisense ODN, 5'-TCC TCC GGA GCC AGA CTT-3'; sense ODN, 5'-AAG TCT GGC TCC GGA GGA-3', and scrambled ODN, 5'-TGA GAC TCC TTA CCG CCG-3'.

ODN exposure and cell cultures. Marrow cells were exposed to ODN as described $(21,23)$. Briefly, $\mathrm{A}^{-} \mathrm{T}^{-} \mathrm{MNC}\left(2 \times 10^{5}\right), \mathrm{CD}^{4} 4^{+}$ MNC $\left(2 \times 10^{4}\right)$, or IGF-IR ${ }^{+}$cells $\left(2 \times 10^{4}\right)$ were incubated in 0.4 $\mathrm{ml}$ of Iscove's modified Dulbecco's medium containing $2 \%$ ( $\mathrm{vol} / \mathrm{vol}$ ) human $\mathrm{AB}$ serum and $10 \mathrm{mM}$ Hepes buffer in polypropylene tubes (Fisher Scientific Co., Pittsburgh, PA). ODN (100 $\mu \mathrm{g} / \mathrm{ml})$ were added at time zero, and $50 \%$ of the initial dose was added again $18 \mathrm{~h}$ later (final concentration $\sim 26 \mu \mathrm{M}$ ). $24 \mathrm{~h}$ after the first addition of ODN, cells were plated in methylcellulose cultures without further washing.

Leukemia cell lines were cultured in RPMI with $2 \%$ heat-inactivated $\left(56^{\circ} \mathrm{C}\right.$ for $\left.0.5 \mathrm{~h}\right) \mathrm{FCS}$. Cells were seeded into $96-$ well microtiter plates $\left(2 \times 10^{4} / \mathrm{ml}\right)$ and then exposed to ODN in a manner identical to that described for normal cell cultures. Cell counts were performed in triplicate on days 4 and 6 after seeding.

Reverse transcription-PCR (RT-PCR). RT-PCR was carried out as reported previously $(21,23)$. In brief, cells $\left(2 \times 10^{5}\right)$ were lysed in $200 \mu \mathrm{l}$ of RNAzol (Tel-Test, Inc., Friendswood, TX) plus $22 \mu \mathrm{l}$ of chloroform. The aqueous phase was collected and subsequently mixed with 1 vol of isopropanol. RNA was precipitated overnight at $-20^{\circ} \mathrm{C}$. The RNA pellet was washed in $75 \%$ ethanol and resuspended in $3 \times$ autoclaved $\mathrm{H}_{2} \mathrm{O}$. RNA $(0.5 \mu \mathrm{g})$ was reverse transcribed with $500 \mathrm{U}$ of

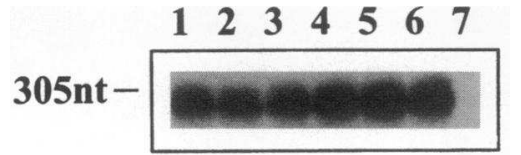

Figure 2. RT-PCR analysis of IGF-I mRNA expression (177 nt) in peripheral blood mononuclear cells $(P B$; lane 1$)$, bone marrow mononu-

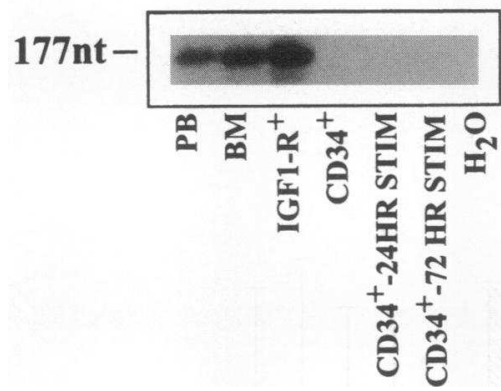

clear cells $(B M$; lane 2$)$, IGF-IR $^{+}$bone marrow mononuclear cells (lane $3), \mathrm{CD} 34^{+}$bone marrow cells (lane 4), $\mathrm{CD}^{+} 4^{+}$ bone marrow cells stimulated with IL-3, IL-6, GM-CSF, KL, and EpO for 24 (lane 5) and $72 \mathrm{~h}$ (lane 6). A PCR reaction containing water instead of RNA is shown in lane 7. Integrity of the RT-PCR reaction and quality of the mRNA extraction are demonstrated by simultaneous amplification of $\beta$-actin mRNA ( 305 nt) from each sample.

Moloney murine leukemia virus reverse transcriptase and $50 \mathrm{pmol}$ of a 20-22-nucleotide (nt) ODN 3' primer complementary to one of the following sequences: (a) IGF-IR codons 20-27 (CTC GAT CAC CGT GCA GTT CT), (b) EpO R nt 850-830 (GCC AGA TCT TCT GCT TCA GAG), and (c) KIT R nt 1201-1179 (CTA GGA ATG TGT AAG TGC CTC C). The resulting cDNA fragments were amplified (35 cycles) using $5 \mathrm{U}$ of Taq polymerase and $5^{\prime}$ primers specific for codons -32-27 (AAG GAA TGA AGT CTG GCT CC) of the reported IGF-IR sequence (24), nt 226-246 (AAC TAC AGC TTC TTC TAC CAG) of the EpO R, or nt 842-864 (GGT TGA CTA TCA GTT CAG CGA G) of the KIT R. $\beta$-Actin mRNA was amplified simultaneously using specific primers as described previously (23). $10 \mu \mathrm{l}$ of amplified product was electrophoresed on a $4 \%$ agarose gel and subsequently transferred to a nylon filter. Filters were prehybridized and then probed with a ${ }^{32} \mathrm{P}$-end labeled ODN specific for the cDNA of interest. Hybridization was detected by autoradiography as described previously (23).

Statistical analysis. Statistical analysis of the data was performed with a MacIntosh computer running the Instat statistical software program.

\section{Results}

Influence of IGF-I on colony formation by human bone marrow cells. We first sought to determine the effect of exogenous rH IGF-I on hematopoietic colony formation. In accord with previously published results (1), we found that IGF-I by itself was unable to stimulate the formation of any lineage's colonies, even when used under low serum conditions and at concentrations up to $100 \mathrm{ng} / \mathrm{ml}$ (data not shown). Similarly, when IGFI was used to supplement cultures stimulated with lineage-appropriate growth factors, no increase in colony formation over that observed with the standard mix of growth factors was observed (Fig. 1). These results were consistent regardless of whether partially purified $\mathrm{A}^{-} \mathrm{T}^{-} \mathrm{MNC}$ or positively selected $\mathrm{CD}^{+} 4^{+}$target cells were used to grow CFU-E, BFU-E, CFUMeg, or CFU-GM.

Of the possible interpretations of these results, two were considered most likely. Either the minute amounts of IGF-I present even in low serum cultures were sufficient for optimal colony formation (2) or human hematopoietic progenitor cells do not respond to IGF-I. The latter would most likely be due to a lack of expression of the IGF-I receptor on colony-forming 
Table II. Comparative Colony-forming Ability of $A^{-} T M N C$. $\mathrm{CD}_{3}^{+}$, and IGF-IR+ Cells

\begin{tabular}{lccc}
\hline Colony & $\begin{array}{c}\mathrm{A}^{-} \mathrm{T} \text { MNC } \\
\left(10^{*} \text { cells plated }\right)\end{array}$ & $\begin{array}{c}\text { CD34 } \\
\left(10^{4} \text { cells plated }\right)\end{array}$ & $\begin{array}{c}\text { IGF-IR } \\
\left(2 \times 10^{4} \text { cells plated }\right)\end{array}$ \\
\hline CFU-E & $325 \pm 164$ & $\mathrm{NT}^{*}$ & $\mathrm{NG}$ \\
BFU-E & $213 \pm 75$ & $192 \pm 62$ & $\mathrm{NG}$ \\
CFU-GM & $392 \pm 93$ & $376 \pm 113$ & $\mathrm{NG}$ \\
CFU-Mix & $\mathrm{NT}$ & $22 \pm 3$ & $\mathrm{NG}$ \\
& & & \\
\hline
\end{tabular}

Results are expressed as mean \pm SD. IGF-IR cells were $>98 \%$ viable as assessed by trypan blue exclusion. * Not tested, no growth.

cells or a lack of IGF-I response despite expression of the receptor. Accordingly, we sought to investigate these possibilities next.

IGF-IR phenotype of normal human bone marrow cells To determine if IGF-IR is expressed on normal hematopoietic progenitor cells, we used several complementary strategies. Our initial approach was to immunochemically phenotype bone marrow cells for CD34 and IGF-IR expression. Analysis of $\mathrm{A}^{-} \mathrm{T}^{-}$ MNC derived from eight normal donors revealed that $\sim 6 \%$ of cells expressed IGF-IR, while $\sim 3 \%$ were CD $34^{+}$(Table I). These results were consistent regardless of the phenotyping method used (FACS ${ }^{\circledR}$ versus immunomagnetic beads ). Accordingly, the IGF-IR ${ }^{+}$cell population was approximately twice as large as the $\mathrm{CD} 34^{+}$population, implying that at least a subset of IGF-IR ${ }^{+}$cells did not coexpress CD34.

Analysis of IGF-IR mRNA expression by sensitive RT-PCR technique further suggested that the $\mathrm{CD}_{3} 4^{+}$and IGF-IR ${ }^{+}$cell populations were completely nonoverlapping. IGF-IR mRNA was unambiguously detected in cells isolated on the basis of IGF-IR expression. In contrast, this mRNA was undetectable in the A T MNC remaining after removal of the IGF-IR ${ }^{+}$ cells (data not shown). Similarly, IGF-IR mRNA was also undetectable in the de novo isolated $\mathrm{CD}_{3} 4^{+}$cell population (Fig. 2 ).

On the assumption that IGF-IR might be expressed on a very small subset of CD34 cells, or might be expressed later in the cells' developmental routine, we stimulated $\mathrm{CD} 34^{+}$cells with a combination of growth factors to expand the progenitor cell populations and stimulate initial development. As shown in Fig. 2, however, even after $24-72 \mathrm{~h}$ of stimulation with IL-3, GM-CSF, KL, EpO, and IL-6, IGF-IR mRNA remained undetectable in the $\mathrm{CD}_{3} 4^{+}$cell population. In contrast, c-kit receptor and erythropoietin receptor mRNA became detectable in the $\mathrm{CD} 34^{+}$population using the same detection strategy, but remained undetectable in the IGF-IR - cells ( data not shown). These results provided additional evidence that the two cell populations were independent. They also suggested IGF-IR expression was not upregulated coincident with, or as a consequence of, initial progenitor cell proliferation/ maturation events.

Hematopoietic colony-forming ability of $I G F-I R^{+}$cells. Since virtually all hematopoietic progenitor cells have been localized to the CD34 cell fraction, the above studies predicted that the IGF-IR ${ }^{+}$cell population would be unlikely to contain any hematopoietic progenitor cells. We tested this supposition directly by examining the ability of positively selected, highly purified IGF-IR - cells to give rise to hematopoietic colonies in methylcellulose cultures stimulated with lineage-appropriate growth factors. Positively selected cells were highly enriched for the desired phenotype when isolated using immunomagnetic beads since only heavily coated cells were used for cloning. In addition, supporting studies with $\mathrm{FACS}^{\circledR}$-isolated IGF-IR cells, which were $>98 \%$ pure (Fig. 3 ), were also carried out. To our knowledge, this strategy for addressing the role of IGFIR in regulating hematopoiesis has not been carried out previously.
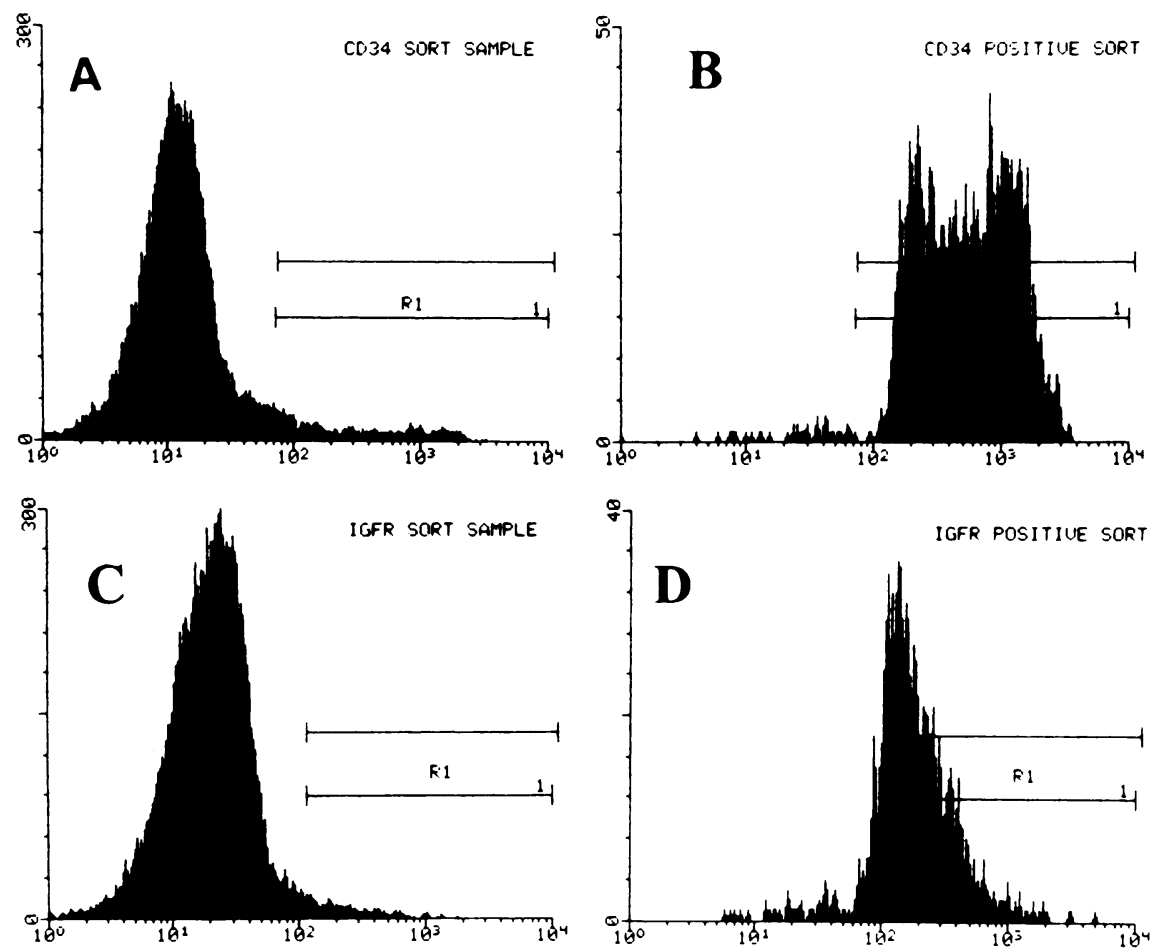

Figure 3. FACS ${ }^{\mathrm{E}}$ histograms demonstrating initial labeling of $\mathrm{CD}_{3} 4^{-}$and IGF-IR cell populations and populations gated on for purification ( $A$ and $C$, respectively). Gates were set so that only cells in the brightest $5 \%$ of the population were sorted. Purity of sorted CD $34^{-}$and IGF-IR populations is demonstrated in $B$ and $D$. respectively, and is $>95 \%$ in each case. 
Table III. Effect of IGF-IR Oligodeoxynucleotides on Hematopoietic Colony Formation by $\mathrm{A}^{-} \boldsymbol{T}^{-}$and/or CD34 ${ }^{+}$Marrow MNC

\begin{tabular}{lcccc}
\hline Colony & Control & IGF-I (S) & IGF-I (AS) & IGF-I (SCR) \\
\hline CFU-E & $472 \pm 108^{*}$ & $496 \pm 53^{*}$ & $493 \pm 48^{*}$ & $506 \pm 73^{*}$ \\
BFU-E & $204 \pm 40 * / 120 \pm 34^{\ddagger}$ & $202 \pm 30 * / 113 \pm 22^{\ddagger}$ & $195 \pm 44^{*} / 113 \pm 14^{\ddagger}$ & $204 \pm 44^{*} / 110 \pm 30^{\ddagger}$ \\
CFU-GM & $311 \pm 77 * / 242 \pm 85^{\ddagger}$ & $291 \pm 44 * / 231 \pm 55^{\ddagger}$ & $305 \pm 42^{*} / 223 \pm 56^{\ddagger}$ & $290 \pm 60^{*} / 230 \pm 34^{\ddagger}$ \\
CFU/Meg & $25 \pm 8^{*}$ & $20 \pm 8^{*}$ & $28 \pm 6^{*}$ & $21 \pm 2^{*}$ \\
CFU-Mix & $21 \pm 8^{\ddagger}$ & $18 \pm 6^{\ddagger}$ & $21 \pm 5^{\ddagger}$ & $21 \pm 3^{\ddagger}$ \\
\hline
\end{tabular}

Results are given as mean \pm SD of three separate studies, each performed in duplicate. Sense $(S)$, AS, and scrambled (SCR) oligomers were added to cultures at a total dose of $150 \mu \mathrm{g} / \mathrm{ml}$. ${ }^{*}$ Colonies derived from $10^{5} \mathrm{~A}^{-} \mathrm{T}^{-} \mathrm{MNC}$ per milliliter. ${ }^{\ddagger}$ Colonies derived from $10^{4} \mathrm{CD} 34^{+} \mathrm{MNC}$ per milliliter.

The results of six separate cell cloning studies, each derived from a different normal donor, are shown in Table II. $\mathrm{A}^{-} \mathrm{T}^{-}$ and $\mathrm{CD}_{34}{ }^{+} \mathrm{MNC}$ gave rise to the expected number of $\mathrm{CFU}$ E, BFU-E, CFU-GM, and CFU-Mix colonies. In distinct contrast, but as predicted, except for a rare cluster of monocytelike cells in cultures stimulated with IL-3 and GM-CSF, no colonies were observed in the cultures seeded with IGF-IR ${ }^{+}$ cells. These results were consistent regardless of whether cells were selected by immunomagnetic beads (Table II) or by flow cytometry. We also examined the possibility that IGF-IR might be expressed on more primitive progenitors than those we were attempting to culture. To assess this, we performed CFU-Blast assays (22) with the same cell populations. Small numbers of CFU-Blast colonies were always obtained from the $\mathrm{A}^{-} \mathrm{T}^{-}$and $\mathrm{CD} 34^{+}$cell populations, but none were ever observed in dishes containing only the IGF-IR ${ }^{+}$cells (data not shown).

Erythroid colony-forming ability of $\mathrm{A}^{-} \mathrm{T}^{-}$cells after depletion of $I G F-I R^{+}$cells or disruption of IGF-IR. As an additional piece of corroborating evidence that IGF-I was not playing a direct role in hematopoietic colony formation, we examined the ability of $\mathrm{A}^{-} \mathrm{T}^{-} \mathrm{MNC}$ to give rise to CFU-E and BFU-E after depletion of IGF-IR ${ }^{+}$cells or after disruption of IGF-IR expression. These experiments were carried out to exclude the possibility that the IGF-IR-positive selection procedures used might artifactually impair colony formation by selected cells or that expression of IGF-IR during a transient but critical phase of hematopoietic cell growth was necessary for colony development. We focused on erythroid colony formation for this aspect of the study because IGF-I has been reported to have the most potent stimulatory effect on CFU-E growth $(12,20)$. Accordingly, potentially subtle growth-promoting effects should have been most recognizable in erythroid colony cultures.

As detailed in Methods, IGF-IR ${ }^{+}$cells were depleted from an $\mathrm{A}^{-} \mathrm{T}^{-} \mathrm{MNC}$ population using immunomagnetic beads. Cells remaining after the depletion were again incubated with the anti-IGF-IR monoclonal antibody at $37^{\circ} \mathrm{C}$ for $1 \mathrm{~h}$ and then cultured as usual. No difference in CFU-E-derived colony formation was observed in cultures containing $\mathrm{A}^{-} \mathbf{T}^{-} \mathrm{MNC}$ or with cells manipulated as just described. The $\mathrm{A}^{-} \mathrm{T}^{-} \mathrm{MNC}$ gave rise to $319 \pm 159 \mathrm{CFU}-\mathrm{E}$ per $10^{5}$ cells cloned, while cells depleted of the IGF-IR ${ }^{+}$population and then exposed again to the antiIGF-IR monoclonal antibody gave rise to $343 \pm 125$ colonies.

To disrupt IGF-IR expression, antisense ODN (AS ODN) were used. Cells were incubated with phosphodiester ODN complementary to codons $21-26$ of the signal sequence of the subunit of IGF-IR preceding the proreceptor sequence as described (25). Sense and scrambled ODN sequences relative to the same codons were used as controls. When compared with growth of colonies observed in either untreated control cells or cells exposed to the control ODN sequences, we observed no significant effect on hematopoietic cell colony formation or apparent maturation, as a result of targeting IGF-IR mRNA expression (Table III). This was true regardless of the target cell population used ( $\mathrm{A}^{-} \mathrm{T}^{-}$versus $\mathrm{CD} 34^{+} \mathrm{MNC}$ ). Fig. $4 \mathrm{dem}-$ onstrates that the IGF-IR AS ODN were capable of downregulating IGF-IR mRNA in the cells positively selected for IGFIR expression. Control ODN had no effect on IGF-IR mRNA expression.

$I G F-I R^{+}$cells elaborate an erythroid colony-stimulating activity. In aggregate, the data presented above strongly suggested that, if IGF-I plays a role in regulating hematopoiesis, the effect is likely both subtle and indirect. To investigate this possibility further, we cocultured positively selected $\mathrm{CD} 34^{+} \mathrm{MNC}$, with or without IGF-IR ${ }^{+}$cells, in the presence or absence of exogenous rH IGF-I (Fig. 5). To increase the likelihood of detecting an effect of the IGF-IR ${ }^{+}$cells, cultures were carried out under low serum conditions and stimulated with IL-3 $(20 \mathrm{U} / \mathrm{ml})$ and $\mathrm{EpO}(5 \mathrm{U} / \mathrm{ml})$ to promote erythropoiesis. In four separate experiments (total dishes/culture condition $=24$ ), there was no difference between the number of BFU-E that formed in cultures containing only $\mathrm{CD} 34^{+}$cells versus those that were cocultured in a 1:1 ratio with $\mathrm{IGF}^{-\mathrm{IR}^{+}}$cells $(84 \pm 50$ vs $91 \pm 42$ colonies; mean $\pm \mathrm{SD} ; P>0.05)$. However, the addition of recombinant IGF-I $(50 \mathrm{ng} / \mathrm{ml})$ to the $1: 1$ cell mix did result in a small but statistically significant $(P<0.02)$ increase in the number of

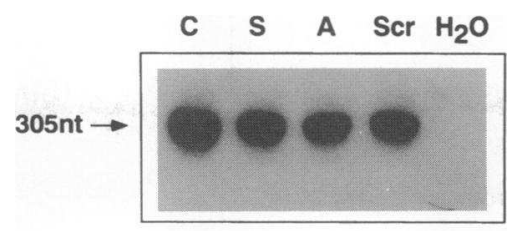

Figure 4. IGF-IR mRNA expression (177 $\mathrm{nt}$ ) in IGF-IR ${ }^{+}$cells exposed to IGF-IR AS ODN as detected by RT-PCR analysis of cell samples. Integrity of the RT-PCR reaction and quality of the mRNA extraction are

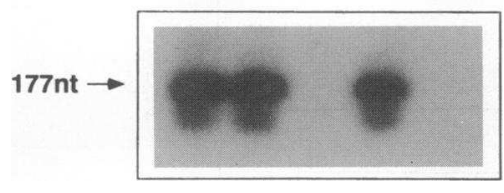
demonstrated by simultaneous amplification of $\beta$ actin mRNA (305 nt) from each sample. $C$, control cells (unexposed to ODN); $S$, cells ex-

posed to sense ODN; $A$, cells exposed to AS ODN; $S c r$, cells exposed to scrambled sequence $\mathrm{ODN}, \mathrm{H}_{2} \mathrm{O}$, negative control PCR reaction containing water instead of RNA. 


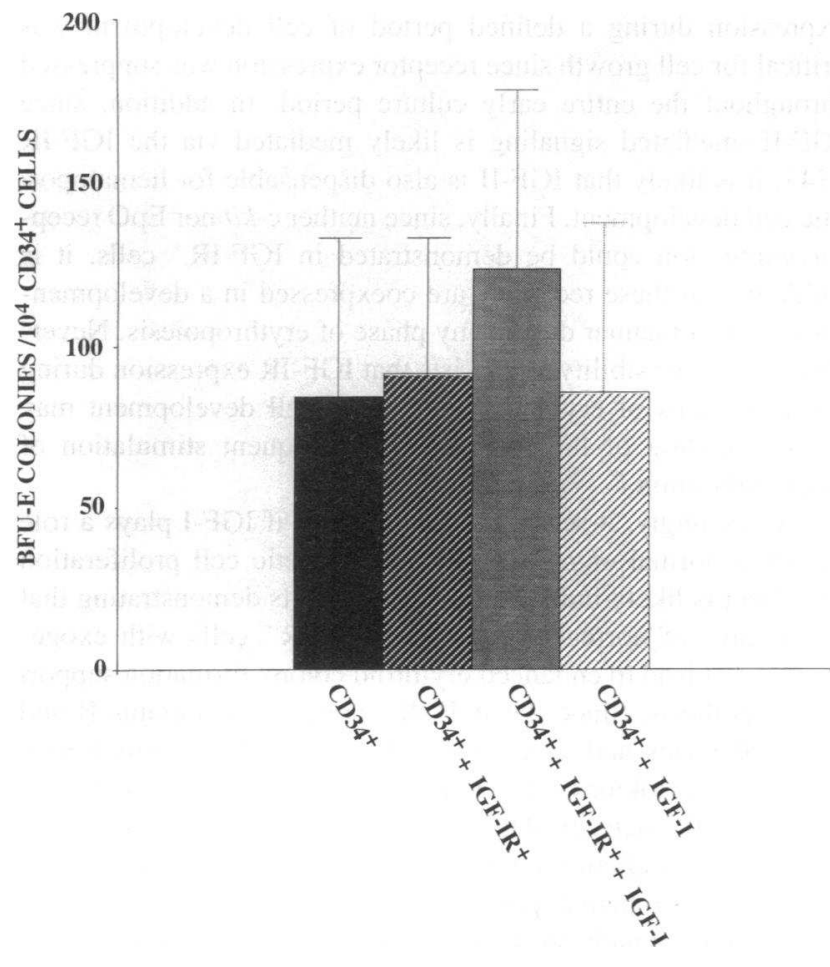

Figure 5. Effect of IGF-IR ${ }^{+}$cells on growth of BFU-E. CD34 ${ }^{+}$marrow cells $\left(10^{4} / \mathrm{ml}\right)$ were cultured alone $(\square)$ or cocultured with IGF$\mathrm{IR}^{+}$cells $(1: 1)$ in the absence $(\square)$ or presence $(\square)$ of $\mathrm{rH}$ IGF-I (50 $\mathrm{ng} / \mathrm{ml})$. The effect of IGF-I alone $(50 \mathrm{ng} / \mathrm{ml})$ on BFU-E colony formation by $\mathrm{CD}_{3}{ }^{+}$cells is also indicated $(\mathbb{\Xi})$. Results presented are mean $\pm S D$ of four separate experiments, each conducted in quadruplicate.

BFU-E colonies formed in the 1:1 cell mix versus the $\mathrm{CD} 34^{+}$ cells alone ( $123 \pm 55$ vs $84 \pm 50)$. As was noted previously, when compared with controls, the addition of rH IGF-I to CD34 ${ }^{+}$ cell cultures containing IL-3 and EpO had no further significant effect on BFU-E colony formation. Accordingly, when stimulated with IGF-I, IGF-IR ${ }^{+}$cells appear to elaborate an activity with modest BFU-E growth-promoting effects. The nature of this activity and whether or not it requires direct cell-cell interactions to be effective remain uncertain.

Role of IGF-I in malignant.hematopoietic cell proliferation. The data presented above suggest that IGF-I plays little, if any, direct role in regulating normal progenitor cell proliferation. Since IGF-I has been reported to stimulate malignant hematopoietic cell growth, we also examined a number of human leukemia cell lines for expression of IGF-IR and whether IGF-I had the ability to stimulate growth of these cells. As shown in Fig. 6, IGF-IR mRNA was detected by RT-PCR in HEL, K562, HL60, MOLT 4, and Jurkat cells. Therefore, IGF-IR was widely expressed in both lymphoid and myeloid cell lines. In addition, among the latter, IGF-IR was expressed in cells expressing markers reflective of granulocyte as well as erythroid and megakaryocyte differentiation. Nevertheless, in spite of this broad range of expression, addition of exogenous recombinant IGF-I had virtually no effect on the proliferation of these various cell types even when cultured under low serum conditions or in serum-free medium (data not shown). Further, in the case of

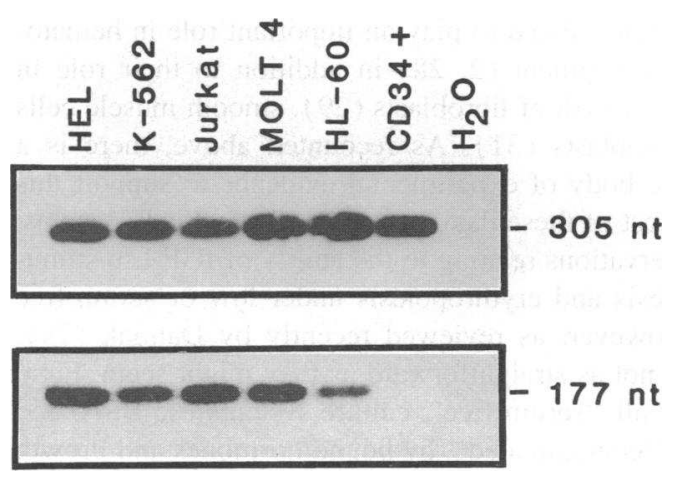

Figure 6. RT-PCR analysis of IGF-IR (177 nt) and $\beta$-actin ( $305 \mathrm{nt})$ mRNA expression in different human leukemia cell lines and CD34 ${ }^{+}$ marrow cells. RNA extraction and cDNA amplification were carried out as described in Methods. $\mathrm{H}_{2} \mathrm{O}$, negative control PCR reaction containing water instead of RNA.

HL-60, HEL, and K562 cells, no significant effect on cell growth was observed when the cells were exposed to IGF-IR AS ODN. Downregulation of IGF-IR was confirmed with HL60 cells by RT-PCR (data not shown).

We also examined primary leukemia patient material for IGF-IR expression and found that 21 of 26 acute myelogenous leukemia (AML) and 2 of 10 chronic myelogenous leukemia patients' cells expressed the receptor as determined by RT-PCR. The effect of IGF-I on the growth of leukemic CFU-GM was investigated in four AML patients who were proven by RTPCR to express the IGF-I receptor. In agreement with the results obtained with human leukemia cell lines, rH IGF-I in amounts up to $50 \mathrm{ng} / \mathrm{ml}$ had no significant effect on the cloning efficiency of these progenitor cells (Table IV). Accordingly, though IGF-IR is expressed in a large percentage of AML blast cells, the functional significance of this expression is presently unclear.

\section{Discussion}

IGF-I is a member of a family of growth factors which signal through receptors with intrinsic tyrosine kinase activity. Ligand/ receptor complexes of this type, such as c-kit/KL and c-fms/ colony-stimulating factor-1, play an important role in regulating the proliferation and differentiation of hematopoietic cells (2628 ). It is not surprising then that IGF-I and its cognate receptor

Table IV. Effect of rH IGF-I on Leukemic CFU-GM Colony Formation

\begin{tabular}{cccc}
\hline Patient & Control & IGF-I $(10 \mathrm{ng} / \mathrm{ml})$ & IGF-I $(50 \mathrm{ng} / \mathrm{ml})$ \\
\hline 1 & $162 \pm 32$ & $156 \pm 18$ & $144 \pm 21$ \\
2 & $61 \pm 28$ & $51 \pm 16$ & $46 \pm 20$ \\
3 & $41 \pm 15$ & $27 \pm 9$ & $41 \pm 7$ \\
4 & $68 \pm 20$ & $38 \pm 24$ & $77 \pm 31$ \\
\hline
\end{tabular}

Colonies derived from $10^{5} \mathrm{~A}^{-} \mathrm{T}^{-} \mathrm{MNC}$ per milliliter. Results are expressed as mean \pm SD of quadruplicate cultures. CFU-GM colony formation was stimulated with IL-3 and GM-CSF in addition to the dose of IGF-I indicated. 
have also been postulated to play an important role in hematopoietic cell development $(2,28)$ in addition to their role in supporting the growth of fibroblasts (29), smooth muscle cells (30), and osteoblasts (31). As recounted above, there is a relatively large body of experimental evidence to support this hypothesis. Most of these data, at least in normal cell systems, consist of observations relating to the ability of IGF-I to stimulate myelopoiesis and erythropoiesis under low or serum-free conditions. However, as reviewed recently by Dainiak (28), these data are not as straightforward as they might seem. First, since virtually all "serum-free" culture systems use BSA, and BSA is often "contaminated" by bound hormones and growth factors, including IGFs, the relative requirements for a given protein are necessarily difficult to determine. Second, the quality and purity of IGFs may vary with the source of the protein (28). Some IGF-II preparations for example, apparently contain varying amounts of precursor isoforms with differing glycosylation patterns and different effects on progenitor cell growth. Third, though great strides have been made in purifying primitive human hematopoietic progenitor cells, "purified" populations are not homogeneous either in regard to their constituents or their developmental potentials. It is perhaps understandable then that conflicts exist in the literature regarding the importance of the IGFs $(32,33)$.

We have addressed some of these problems by examining the importance of IGF-I in hematopoiesis with strategies not used previously. First, we have attempted to understand the importance of IGF-I by studying the developmental potentials of bone marrow cells that express the receptor. This direct approach has not been reported before. With it, one might predict that if the binding of IGF-I to hematopoietic progenitor cells was of critical importance for proper development, it would be easiest to detect this requirement in IGF-I-expressing cells. As a correlative experiment, we also sought to define when in hematopoietic cell development the IGF-I receptor was expressed since previous studies have only demonstrated expression at the relatively late developmental level of the CFU-E. Again, if the receptor/ligand axis is important early in hematopoiesis, one might predict expression of IGF-IR in cells more primitive than the relatively mature CFU-E. Finally, in recognition of the fact that it is extremely difficult to obtain a homogenous population of primitive hematopoietic progenitor cells and that IGF-IR might be expressed on cells at densities too low for immunologic separation methods, we inhibited IGF-I receptor expression with antisense oligodeoxynucleotides.

To our surprise, we found that IGF-IR ${ }^{+}$cells, in marked contrast to $\mathrm{CD}_{3} 4^{+}$and $\mathrm{A}^{-} \mathrm{T}^{-} \mathrm{MNC}$, contained essentially no clonable hematopoietic progenitor cells. Though we occasionally observed the formation of small, macrophage-like clusters of cells in IGF-IR ${ }^{+}$cell cultures, we never observed any erythroid colonies. Given previous reports that IGF-I stimulates erythropoiesis and that late erythroid progenitor cells express the IGF-IR, this finding was particularly perplexing. Accordingly, we performed a number of different experiments designed to corroborate these results. First, we found that rH IGF-I had little effect on hematopoietic colony formation and that removal of IGF-IR ${ }^{+}$cells from $\mathrm{A}^{-} \mathrm{T}^{-}$MNC had no effect on the numbers of CFU-E cloned from these cells. Similarly, disruption of IGF-IR expression with antisense oligodeoxynucleotides also had no effect on numbers of any hematopoietic colonies formed. The latter experiment was informative in other ways as well. For example, the results obtained made it unlikely that IGF-IR expression during a defined period of cell development was critical for cell growth since receptor expression was suppressed throughout the entire early culture period. In addition, since IGF-II-mediated signaling is likely mediated via the IGF-IR (34), it is likely that IGF-II is also dispensable for hematopoietic cell development. Finally, since neither c-kit nor EpO receptor expression could be demonstrated in IGF-IR ${ }^{+}$cells, it is unlikely that these receptors are coexpressed in a developmentally critical manner during any phase of erythropoiesis. Nevertheless, the possibility still exists that IGF-IR expression during the final steps of erythroid or myeloid cell development may permit binding of the ligand with consequent stimulation of final maturation.

Accordingly, it seems most likely that if IGF-I plays a role in either normal or malignant hematopoietic cell proliferation the effect is likely indirect. Our experiments demonstrating that admixtures of normal CD34 ${ }^{+}$and IGF-IR ${ }^{+}$cells with exogenous IGF-I lead to enhanced erythroid colony formation support this hypothesis. Since the IGF-IR ${ }^{+}$population contains B and $T$ lymphocytes and monocytes $(35,36)$, both of which may synthesize cytokines $(27,37)$, it may be that these cells are producing the activity detected. These results also explain the apparent contradiction between the proposed importance of the IGFs in in vitro hematopoietic cell development and the clinical observations which suggest otherwise. Animals and humans with isolated growth hormone deficiency have no obvious hematologic abnormalities $(2,38,39)$. Similarly, acromegalic patients who suffer from unregulated production of growth hormone do not have the enhanced erythropoiesis that is seen in patients with elevated erythropoietin levels (40). Therefore, while recent "knockout" experiments point out the importance of IGFs for fetal development in the mouse $(41,42)$, our results suggest that in the adult organism IGFs are not required, or even necessary, for normal or malignant hematopoietic cell development.

\section{Acknowledgments}

The editorial assistance of E. R. Bien is gratefully acknowledged.

This work was supported in part by U.S. Public Health Service grants CA 36896, CA 01324, CA 54384, HL 46668, and CA 51083 (A. M. Gewirtz).

\section{References}

1. Humbel, R. E. 1990. Insulin-like growth factors I and II. FEBS (Fed. Eur. Biochem. Soc.) Lett. 190:445-462.

2. Hooghe, R., M. Delhase, P. Vergani, A. Malur, and E. L. Hooghe-Peters. 1993. Growth hormone and prolactin are paracrine growth and differentiation factors in the hematopoietic system. Immunol. Today. 14:212-214.

3. Boyer, S. H., T. R. Bishop, O. C. Rogers, A. N. Noyes, L. P. Frelin, and S. Hobbs. 1992. Roles of erythropoietin, insulin-like growth factor 1, and unidentified serum factors in promoting maturation of purified murine erythroid colony-forming units. Blood. 80:2503-2512.

4. Kurtz, A., W. Jelkmann, and Ch. Bauer. 1982. A new candidate for the regulation of erythropoiesis. FEBS (Fed. Eur. Biochem. Soc.) Lett. 149:105-108.

5. Murphy, J. W., G. Tsarfaty, and D. L. Longo. 1992. Growth hormone exerts hematopoietic growth-promoting effects in vivo and partially counteracts the myelosuppressive effects of azidothymidine. Blood. 80:1443-1447.

6. Clark, R., J. Strasser, S. McCabe, K. Robbins, and P. Jardieu. 1993. Insulinlike growth factor-1 stimulation of lymphopoiesis. J. Clin. Invest. 92:540-548.

7. Landreth, K. S., R. Narayanan, and K. Dorshkind. 1992. Insulin-like growth factor-1 regulates pro-B cell differentiation. Blood. 80:1207-1212.

8. Gibson, L. F., D. Piktel, and K. S. Landreth. 1993. Insulin-like growth factor-1 potentiates expansion of interleukin-7 dependent pro-B cells. Blood. 82:3005-3011.

9. Estrov, Z., R. Meir, Y. Barak, R. Zaizov, and Z. Zadik. 1991. Human 
growth hormone and insulin-like growth factor-1 enhance the proliferation of human leukemic blasts. J. Clin. Oncol. 9:394-399.

10. Pepe, M. G., N. H. Ginzton, P. D. K. Lee, R. L. Hintz, and P. L. Greenberg. 1987. Receptor binding and mitogenic effects of insulin and insulin like growth factors I and II for human myeloid leukemic cells. J. Cell. Physiol. 133:219227.

11. Merchav, S., I. Tatarsky, and Z. Hochberg. 1988. Enhancement of erythropoiesis in vitro by human growth hormone is mediated by insulin-like growth factor 1. Br. J. Haematol. 70:267-271.

12. Sawada, K., S. B. Krantz, E. N. Dessypris, S. T. Koury, and S. T. Sawyer. 1989. Human colony-forming units-erythroid do not require accessory cells, but do require direct interaction with insulin-like growth factor I and/or insulin for erythroid development. J. Clin. Invest. 83:1701-1709.

13. Correa, P. N., and A. Axelrad. 1991. Production of erythropoietic bursts by progenitor cells from adult human peripheral blood in an improved serum-free medium: role of insulin like growth factor 1. Blood. 78:2823-2833.

14. Akahane, K., A. Tojo, A. Urabe, and F. Takaku. 1987. Pure erythropoietic colony and burst formations in serum-free culture and their enhancement by insulin-like growth factor 1. Exp. Hematol. (NY). 15:797-802.

15. Sanders, M., S. Sorba, and N. Dainiak. 1993. Insulin-like growth factor stimulate erythropoiesis in serum-substituted umbilical cord blood cultures. Exp. Hematol. (NY). 21:25-30.

16. Merchav, S., I. Tatarsky, and Z. Hochberg. 1988. Enhancement of human granulopoiesis in vitro by biosynthetic insulin-like growth factor I/somatomedin $\mathrm{C}$ and human growth hormone. J. Clin. Invest. 81:791-797.

17. Fu, Y. K., S. Arkins, B. S. Wang, and K. W. Kelley. 1991. A novel role of growth hormone and insulin-like growth factor-1. Priming neutrophils for superoxide anion secretion. J. Immunol. 146:1602-1608.

18. Huang, S., and W. M. M. Terstappen. 1992. Formation of hematopoietic microenvironment and hematopoietic stem cells from single human bone marrow stem cells. Nature (Lond.). 360:745-749.

19. Reiss, K., P. Porcu, C. Sell, Z. Pietrzkowski, and R. Baserga. 1992. The insulin-like growth factor 1 receptor is required for the proliferation of hemopoietic cells. Oncogene. 7:2243-2248.

20. Cotton, E. W., R. T. Means, S. M. Cline, and S. B. Krantz. 1991. Quantitation of insulin-like growth factor-1 binding to highly purified human erythroid colony-forming units. Exp. Hematol. (NY). 19:278-281.

21. Ratajczak, M. Z., S. M. Luger, K. DeRiel, J. Abrahm, B. Calabretta, and A. M. Gewirtz. 1992. Role of the KIT protooncogene in normal and malignan human hematopoiesis. Proc. Natl. Acad. Sci. USA. 89:1710-1714.

22. Leary, A. G., Y. Hirai, T. Kishimoto, S. C. Clark, and M. Ogawa. 1989. Survival of hemopoietic progenitors in the $\mathrm{G}_{0}$ period of the cell cycle does not require early hemopoietic regulators. Proc. Natl. Acad. Sci. USA. 86:4535-4538.

23. Ratajczak, M. Z., N. Hijiya, L. Catani, K. DeRiel, S. M. Luger, P. McGlave, and A. M. Gewirtz. 1992. Acute- and chronic-phase chronic myelogenous leukemia colony-forming units are highly sensitive to the growth inhibitory effects of c-myb antisense oligodeoxynucleotides. Blood. 79:1956-1961.

24. Ullrich, A., A. Gray, A. W. Tam, T. Yang-Feng, T. Tsubokawa, C. Collins W. Henzel, T. Lebon, S. Tathuria, E. Chen, et al. 1986. Insulin growth factor-1 receptor primary structure: comparison with insulin receptor suggest structural determinants that define functional specificity. EMBO (Eur. Mol. Biol. Organ.) J. 5:2503-2512.
25. Pietrzkowski, Z., C. Sell, R. Lammers, A. Ullrich, and R. Baserga. 1992. Roles of insulin like growth factor-1 and the IGF-1 receptor in epidermal growth factor stimulated growth of 3T3 cells. Mol. Cell. Biol. 12:3883-3889.

26. Ratajczak, M. Z., S. M. Luger, and A. M. Gewirtz. 1992. The c-kit protooncogene in normal and malignant human hematopoiesis. Int. J. Cell Cloning. 10:205-214.

27. Nicola, N. A. 1989. Hemopoietic cell growth factors and their receptors. Annu. Rev. Biochem. 58:45-77.

28. Dainiak, N. 1993. Control of hematopoietic cell growth by somatomedins. Exp. Hematol. (NY). 21:1405-1407.

29. Pardee, A. B. 1989. $G_{1}$ events and regulation of cell proliferation. Science (Wash. DC). 246:603-608.

30. Florini, J. R., D. Z. Ewton, S. L. Falen, and J. J. Van Wyk. 1986. Biphasic concentration dependency of stimulation of myoblast differentiation by somatomedins. Am. J. Physiol. 250:C771-C778.

31. Schmid, C., T. Steiner, and E. R. Frosch. 1984. Insulin-like growth factor I supports differentiation of cultured osteoblast like cells. FEBS (Fed. Eur. Biochem. Soc.) Lett. 173:48-52.

32. Ratajczak, M. Z., W. I. Kuczynski, J. Moore, J. Ratajczak, and A. M. Gewirtz. 1992. A reappraisal of the function of insulin like growth factor-1 (IGF1 ) in the regulation of normal human erythropoiesis. Blood. 80 (Suppl. 1): 151 a. (Abstr.)

33. Dai, C. H., S. B. Krantz, and K. M. Zsebo. 1991. Human burst-forming units-erythroid need direct interaction with stem cell factor for further development. Blood. 78:2493-2497.

34. Sara, V. R., and K. Hall. 1990. Insulin-like growth factors and their binding proteins. Physiol. Rev. 70:591-614.

35. Stuart, Ch. A., R. T. Meehan, L. S. Neale, N. M. Cintron, and R. W. Furlanetto. 1991. Insulin-like growth factor-1 binds selectively to human peripheral blood monocytes and B-lymphocytes. J. Clin. Endocrinol. \& Metab. $72: 1117-1122$.

36. Kooijman, R., M. Willems, C. J. C. De Haas, G. T. Rijkers, A. L. G. Schuurmans, S. C. Van Buul-Offers, C. J. Heijnen, and B. J. M. Zegers. 1992. Expression of type 1 insulin-like growth factor receptors on human peripheral blood mononuclear cells. Endocrinology. 131:2244-2250.

37. Feldman, L., J. G. Frazier, and A. J. Sytkowski. 1992. B-lymphocytederived burst promoting activity is a pleiotropic erythroid colony-stimulating factor, E-CSF. Exp. Hematol. (NY). 20:1223-1228.

38. Kiess, W., S. Malazowski, M. Gelato, O. Butenand, H. Doerr, B. Crisp, E. Eisl, A. Maluish, and B. H. Belohradsky. 1988. Lymphocyte subset distribution and natural killer activity in growth hormone deficiency before and during shortterm treatment with growth hormone releasing hormone. Clin. Immunol. Immunopathol. 48:85-94.

39. Dumont, F., F. Robert, and P. Bischoff. 1979. T and B lymphocytes in pituitary dwarf Snell-Bagg mice. Immunology. 108:1578-1585.

40. Erslev, A. J. 1983. Secondary polycythemia (erythrocytosis). In Hematology. W. J. Williams, E. Beutler, A. J. Erslev, and M. A. Lichtman, editors. McGraw-Hill Inc., New York. 673-684.

41. Liu, J. P., J. Baker, A. S. Perkins, E. J. Robertson, and A. Efstratiadis. 1993. Mice carrying null mutations of the genes encoding insulin-like growth factor I (IGF-1) and type 1 IGF receptor (IGFI-R). Cell. 75:59-72.

42. Baker, J., J. P. Liu, E. J. Robertson, and A. Efstratiadis. 1993. Role of insulin-like growth factors in embryonic and postnatal growth. Cell. 75:73-82. 